\title{
Universal Values: Spread in China and the Essence
}

\author{
Yonghong Zhang \\ School of Marxism, Research Center for Marxist Theory, Southwest University, Chongqing 400715, China
}

\begin{abstract}
To explore the "universal values" ideology with the Western "democracy, freedom, equality, human rights and so forth" as the core can enhance our understanding of it. The so-called "Universal values" are the core values of the West. Its spread in China has a profound background both internationally and domestically. This ideology has had a negative influence on people, resulting in a transmutation of their world outlook. Only by using the Marxist class viewpoint and class analysis approach, could we boycott its negative effects.
\end{abstract}

Key words: Universal value, the West, China, class analysis

\section{Introduction}

Freedom, democracy, equality and human rights are shared values and commonly created civilization in the history of mankind. Admittedly, Freedom, democracy, human rights and other social systems in the West have contributed to the development and progress of society, so they are worth learning from by other countries. However, some people whereby call core concept of the West "universal values" and demand the world, especially China conform with it. I am afraid they have ulterior motives in view. In recent years, the so-called "universal values" are very popular, and are gradually evolving into a social trend of thought. Thus, to study the connotation, occurrence background, formation process and main points of "universal values" becomes one of the most urgent problems.

\section{The Connotation of "Universal Values"}

In recent years, "universal values" have become the focus of academic research for many scholars and experts. Broadly speaking, around the meaning of "universal values", five perspectives could be broadly summarized. The first is to define "universal values" by semantics. Thus, there are two different understandings: on the one hand, some scholars believe that "universal values", by definition, should include the following two aspects:

First, the values could be applied to all people; whichever class and whichever person are in favor of such values; that is, they have universal applicability; Second, the values are applicable to any society and whatever socio-economic patterns; that is, they are permanent in the history of mankind. On the other hand, some scholars have argued that "universal values" don't necessarily apply to everyone, they could also be things applied to most of the people in the world, because this is not a question of whether they have universal values, but only a question of the degree of their universality.

The second argument is to explore "universal values" from the dimension of religion. It's generally believed that the concept of "universal value" comes from medieval Europe's "universalism". The so-called "universalism" emphasizes the supremacy of God, while human rights are ignored, thereby to provide the theoretical support for the feudal lords to exploit serfs. Some people also point out that the so-called "universal values" are to make "good and evil", "awe" in religion become commandments observed by all the people.

The third view is discussed from an ethical dimension. People believe that "universal value" has the same meaning as "universal ethics" and" global ethics", and they could be promoted around the world. However, it should be noted that most of the ethical principles are concepts and guidelines people spun off from a complete system. If they are restored to the original system, their connotations and extensions may be totally different.

The fourth view is expounded from a philosophical dimension. For example, some people emphasize the commonality of values and see some values as things that hold true for the whole world. Some people believe that there are objective universal values, which are the basis for the development of human society and independent of man's will. 
The fifth view is discussed from the dimension of politics or ideology. For example, some scholars believe that, with the progress of globalization, humanity is to address issues such as energy crisis, ecological crisis, environmental pollution, terrorism, financial crisis and other global issues, and they need to adopt a global governance, "globalism" or "universal values" are therefore promoted. Some other scholars believe that the so-called "universal values" are actually the absolute eternal values advocated by Western countries, such as freedom, democracy, equality, and human rights.

The above study shows that people define "universal values" differently, thus leading to a variety of positions, perspectives and viewpoints. No doubt, we should "let a hundred flowers blossom and a hundred schools of thought contend" and allow scholars from different areas to study and explore "universal values". However, people speak indiscriminately of "universal values" and confuse the boundaries between life discourse, academic discourse and political discourse of "universal values", so that views from different experts in various fields come into conflict with each other. The reason is that people arrive at very different conclusions from specific areas of research, and their conclusions are liable to spark heated public suspicion. Thus, to clarify the concept of "universal values" should be the first step for an indepth exploration of this trend of thought.

In my opinion, the so-called "universal values" are the core values of the West, which regard bourgeois as the inventor, monopoly, exporter and determiner of the universal values such as democracy, freedom, fraternity and human rights. That is, they, with distinct political demands and ideological tendencies, are advocating and disseminating the core value systems of the West behind a deceptive veil.

\section{The Background and the Spreading Process of "Universal Values" Ideology}

\section{The background of "universal values" ideology in China}

An international context

Internationally, the "universal values" ideology is widely spread under the impulsion of the Western academics and organizations. This could be explained by both the changeless element and changing elements in the international background. On the one hand, the so-called "changeless element" refers to the fact that some Westerners undoubtedly think their values and institutional system are the "most perfect "and "undoubtedly the most correct", and they always enjoy bestowing them on the people of the world. This sense of "superiority" and "mission" remains unchanged. Meanwhile, the Western capitalist countries have never given up and stopped "peaceful evolution" towards socialist China. By virtue of their economic and technological advantages, they promote and disseminate core values of capitalism, with the aim of "dividing "and "Westernizing" socialism with Chinese characteristics, and ultimately subverting the socialist system with Chinese characteristics.

On the other hand, the so-called "changing elements" need to be explained as follows:

First, with the enhancement of China's comprehensive national strength and political and economic ties in the world getting closer and closer, the Western countries have rapidly adjusted their strategic schemes with the change of times; that is, in addition to taking "containment" policy, they pay more attention to "touch" policy, in an attempt to "win without fighting". Especially in recent years, "street politics" and "color revolution" pushed by the West (e.g., Georgia's "Rose Revolution" and Ukraine's "Orange Revolution") have frequently succeeded in the Central Asian countries, which further strengthens the Chinese practice of "peaceful evolution" and "win without fighting" strategy of the West through the socalled "universal values" approach.

Second, the Western hegemony expression ways and value permeation ways have changed. With the acceleration of the process of economic globalization, the world has increasingly become an indivisible organic whole. To solve global issues such as environmental pollution, ecological crisis, transnational crimes, terrorist threats, financial turmoil, and nuclear radiation requires friendly consultations between countries; and to prevent cultural conflicts, "common values" in global governance are needed. Thus, "universal values" derived from the "global ethics" are favored by the West. They take the opportunity to have "ideological neutrality"," end of ideology" and other deceptive ideas as "theory opiums",and use strong science and technology such as internet to promote such "universal values" as democracy, freedom, fraternity and human rights, the essence of which, without doubt, is to lure people to agree with the core values of the West.

\section{A domestic context}

Thirty years of China's reform and opening up has made brilliant achievements: Economic strength has greatly increased; foreign reserves rank first in the world; the total GDP has surpassed Japan and ranks second in the world. To some extent, a breakthrough in the reform of the economic system has been 
achieved, but at the same time, as reform deepens, difficult issues and institutional conflicts will emerge in quick succession, and the difficulty of our tasks is set to increase, which requires us to be more cautious in economic development. Meanwhile, along with the profound changes in the economic system, the current economic reform and opening up is no longer confined to material sphere, but has already touched culture, values, political system. In this case, how to sum up the experience of 30 years' reform and opening up and further deepen the reform becomes a major issue we must face.

On the one hand, in the process of social transformation, people's employment styles, the pace of life, social benefit distribution ways and competition manners have undergone great changes. Alvin Toffler said that we cannot cram the embryonic world of tomorrow into yesterday's conventional cubby holes. Therefore, to adapt to the change of economic system, people's ideas and values are also being constantly adjusted.

On the other hand, China's political reform also needs to adapt to changes in the economic system to move forward and continue to improve. Resistance and difficulty for reform are unprecedented and the reform is to go slowly; otherwise, it could easily lead to social chaos and ultimately hinder economic and social development. At the same time, China's social problems have become increasingly prominent in recent years, which causes ideological confusion and value transmutation. It's in this context that "universal values" have emerged and spread, and gradually become a major social trend of thought concerned with ideological tendencies.

In summary, the emergence and spread of "universal values" ideology in China are not groundless, but have intricate background both internationally and domestically.

\section{The spreading process of "universal values" ideology in China}

"Universal values" ideology is apparently associated with "ecumenism", which has its root in the Greek word "oikoumene", meaning the whole inhabited world. In $395 \mathrm{AD}$, the Roman Empire was divided into eastern and western empires, and Christianity also differentiated into eastern and western factions. The concept of ecumenism was first used by the Christian East and West factions to compete for the influence in the entire Roman Empire. After World War I, a number of Protestant churches in Europe launched the ecumenical movement.

The general understanding of the ecumenical movement is that it came from the Roman Catholic Church's attempts to reconcile with Christians who had become separated over theological issues. The movement led to an understanding amongst the churches that despite difference they could join together to be an element of great change in the world. To be an agent of hope and peace amongst the chaos and destruction that humans seem to create. The movement resulted in not only ecumenism but the forming of councils amongst the denominations that connected churches across continental lines.

China's use of the concept of "universal value" develops from the concept of "universal ethics", while the "universal values" ideology concerned with ideological tendencies began to emerge in the 1990s. In 1990, German theologian Hans Kueng published his book Global Responsibility, which initially raise about the universal ethics.

In 1993, the famous world-renowned Harvard scholar Samuel Huntington published an article titled The Clash of Civilizations? In the magazine Foreign Affairs. He initially made his famous "clash of civilizations" theory and advocated "play down the ideology", and in 1996, he published the book The Clash of Civilizations and the Remaking of World Order, illustrating the concept of "universal civilization" with the tint of West-centered Theory. This concept then caused a fierce reaction and controversy in China. In the same year, the Parliament of World Religions held in Chicago discussed and adopted Global Ethics: Declaration of the World Parliament of Religions, which was translated into English and spread to China in 1997.

In 1999, to commemorate the 80th anniversary of the "May Fourth" Movement, Harvard University Professor Tu Weiming and Sun Yat-Sen University Professor Yuan Weishi started a dialogue, agreeing that "human rights, freedom, democracy, rule of law and constitutional government" are all "fundamental values that hold true for the whole world". However, the discussion about the "universal values" at this time mainly concentrated in the academic field, and had no sharp ideological color. With the development of argumentation, some people both in the West and at home weren't satisfied with academic discussions, but went in depth to the aspect of political ideology.

In 2003, some of the self-proclaimed "liberals" put forward the "democratic revision of the constitution" and demanded deletion of the Preamble to the Constitution including the four cardinal principles. From 2003 to 2005, "color revolutions" happened in succession in Georgia ("Rose Revolution"), Ukraine ("Orange Revolution"), and Kyrgyzstan ("Tulip Revolution"), which further stimulated the nerves of some persons from both home and abroad, so that they were keen to publicize the "universal values" ideology. 
In October 2005, domestic and foreign hostile forces and some liberal intellectuals attacked and negated China's socialist democratic politics using "democracy"-the so-called "universal value"-as the theoretical weapon.

In 2006, some people at the so-called Western Hills meeting openly pointed out that the goal of "constitutionalism" is to achieve multi-party system, and hoped nationalization of the military. Since 2007, driven deliberately by some newspapers and websites, the concept of "universal values" began wantonly spreading.

Later, it was hyped up by some people's taking occasions of Wenchuan earthquake, the Olympic Games and Paralympic Games, finally becoming a force which shouldn't be neglected.

\section{The Main Ideas and Essence of the "Universal Values" Ideology}

Abstract theory of human nature and humanism are the philosophical and theoretical basis of "universal values" ideology. On the one hand, advocators of "universal values" believe that, in the study of human nature, people should put aside the social and class nature of humanity to understand and consider the universal nature of humanity, which, undoubtedly, denies and castrates the class and social properties of humanity, and sees human nature as something out of touch with the times.

On the other hand, some people tend to exaggerate the common interests of mankind, and advocate the socalled "human interests above everything". They refer to the core philosophy and the system mode of the West as" humane", while label different values and social systems as "inhuman", which, indeed, serves the neo-colonial expansion of developed capitalist countries.

Marx pointed out:" the essence of man is no abstraction inherent in each single individual. In reality, it is the ensemble of the social relations." In the sixth Thesis on Feuerbach (1845), Marx criticizes the traditional conception of "human nature" as "species" which incarnates itself in each individual, on behalf of a conception of human nature as formed by the totality of "social relations". Thus, the whole of human nature is not understood, as in classical idealist philosophy, as permanent and universal: the species-being is always determined in a specific social and historical formation.

No doubt, "universal values" such as "democracy", "freedom", "rationality" and "fraternity" can't stand reasoning. Deng Xiaoping once pointed out," I am amazed to find that some of our Party comrades are preaching humanism, the value of the human beings and so forth in abstract terms. They don't understand that neither in capitalist society nor in socialist society can there be an abstract value of the human being or abstract humanism, because even in our society there are still bad people, dregs of both the old and new societies......Discussion of human beings apart from these specific conditions and tasks is discussion not of real human beings but of abstractions; this is not Marxist approach, and it will lead young people astray."

In this regard, we could only understand the essence of "universal values" ideology by adhering to the Marxist view of class and class analysis approach. Class analysis is research in sociology, politics and economics from the point of view of the stratification of the society into dynamic classes.

It implies that there is no universal or uniform social outlook, rather that there are fundamental conflicts that exist inherent in society. That we corrected our mistakes in taking class struggle as the central task is quite right, but that does not mean that the class struggle no longer exists. As long as the class struggle still exists in a certain range, we cannot discard Marxist class analysis and class viewpoint. What we need to do is to employ the Marxist class viewpoint and class analysis approach to identify and analyze the hypocritical and deceptive nature of "universal values" ideology.

\section{Conclusion}

Some people try intentionally to lead the "universal values" towards political ideological aspect and give universal significance to the Western democracy, freedom, fraternity and other ideas and the basic systems, asking other countries to imitate and comply with them. They are keen to spread and beautify the Western core values and social systems. As for these so-called "universal values", they are essentially a reflection of the interests of a certain class or some groups, but by no means all human beings. To fully recognize and guard against the erosive function of the "universal values" is of great realistic significance to developing countries.

As we have already noticed, this ideology has had a negative influence on people, particularly young people in China, resulting in a transmutation of people's world outlook. In my opinion, only by using the Marxist class analysis approach, could we wake up to this ideology and boycott its negative effects.

\section{References}

Huntington, Samuel P. (1993). The clash of civilizations? Foreign Affairs, pp.22-49. 
Huntington, Samuel P. (2011). The Clash of Civilizations and the Remaking of World Order. New York: Simon \& Schuster. Kueng, Hans (1991). Global Responsibility: In Search of a. New World Ethics. London: SCM Press.

Selected Works of Deng Xiaoping (1994). Beijing: Foreign Languages Press. vol.3,
Selected Works of Marx and Engels (1995). Beijing: People's Publishing House. vol1,

Wen, Ping (2009). Analysis of "universal values". Hongqi Digest, pp.4-9.

Zhou, Xin Cheng (2008).A discussion of "universal values". Mrxism Studies, pp.25-28. 